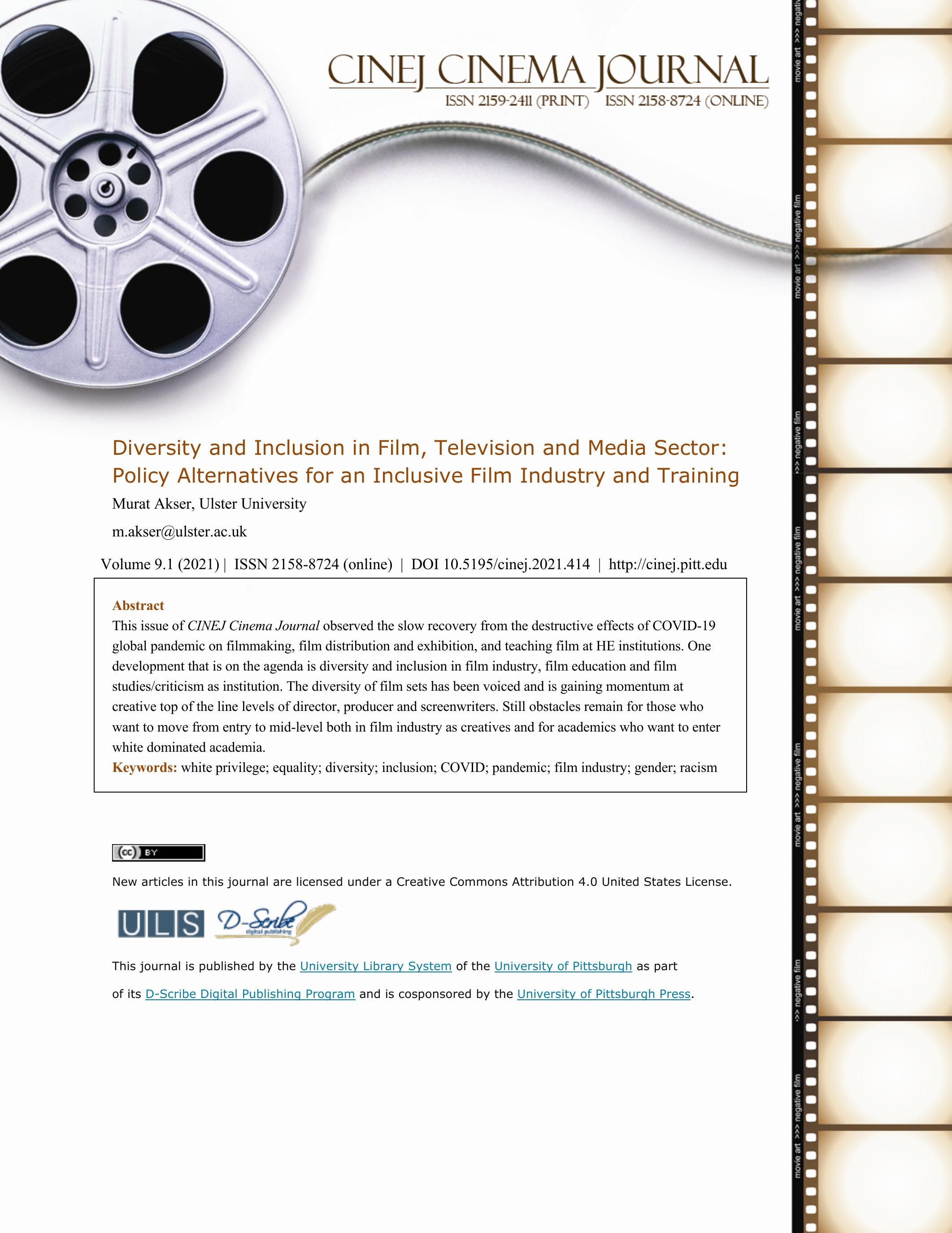




\section{Diversity and Inclusion in Film, Television and Media Sector: Policy Alternatives for an Inclusive Film Industry and Training Murat Akser}

Debates around the diversity and inclusion in film/television industry have been gaining momentum right before the COVID-19 pandemic hit the industry hard (Akser, 2020; Eikhof, 2020; Lourenço, 2021). Through furlough schemes most of the film/tv workers were able to keep aloft the economic hardships and due to increased demand of streaming services under lockdown, more media content was produced than ever. A recent news article even states that the film/tv production is now at its highest (Sweeney, 2021). Yet the majority of the film/tv business is run by at high, mid and even low levels by white men. This is a showcase industry of white privilege, closed to women, black people, immigrants, namely anybody outside the dominant norm of the last century in terms of industrial relationships.

There are encouraging examples of more women entering the higher echelons of film writing and directing. The academy (AMPAS), CBS, BBC Writers Room, Netflix through Canadian Film Centre are all creating new scholarships for women and ethnically diverse talent for new opportunities in the industry. The issues of bullying, harassment and exploitation have now been better addressed. The new intimacy coordinators on film sets make is a safer place for women to work as actors as Michaela Coel dedicated her best actress BAFTA award for I May Destroy You to her intimacy coordinator on set, Ita O'Brien (who also coordinated Normal People) (Brown 2021). And let us not forget agism as another obstacle in film business, as well as indigenous talent almost absent from screens. Such institutional racism in film industry have been explored by researchers intensively in the last decade (Grugulis and Stoyanova, 2012; Jones and Pringle, 2015; Nwonka and Malik, 2018; Hennekam and Syed, 2018). For old establishment 
such as Hollywood Foreign Press Association that gives annual Golden Globes, the failure to change results in erosion of reputation and boycotts (Pulver, 2021). The privileged white male old guard resist the change towards diversity and inclusion as researchers found (Cobb, Newsinger, and Nwonka, 2020; Brook, O'Brien, and Taylor, 2021). In Canada, news of scores of unmarked graves of indigenous people has raised the question of centuries long oppression under white men and for creative industries the representation and inclusion of diverse populations (Meadows, 1994). Canadian government initiatives, such as Ontario's dedicated program for universities to hire black faculty is a correct step forward (Redden, 2020). Similarly, the equality, diversity and inclusion initiatives taken by further and higher education institutions like Sheridan College, OCAD University, York University, Ryerson University and University of Toronto give hope for training and employment of diverse faculty for the next generation (Davis, Shtern, Coutanche and Godo, 2018). The future of equality, diversity and inclusion lies also through facing/learning from/not repeating the mistakes of the past in hiring and work practices regarding older people, women, LGBTQIA+, BAME, indigenous peoples, immigrants in film and television industry and academia. One could start the investigation into and policy proposals towards the elimination of possible discriminatory policies around IATSE, NABET and university HR $(\mathrm{P} \& \mathrm{C})$ processes of the last 20 years.

This issue of $C I N E J$ was prepared from around 100 submissions made within a period of six months. All submissions were rigorously double blind refereed. The editors admit that finding two specialised referees in diverse fields of film studies has been a challenge. Majority of film studies scholars have been under serious pressure from COVID-19 pandemic related work from 
home stress. Still, we have been blessed to have around 200 blind referees guide us and the authors through quality film studies scholarship.

As usual we had high quality submissions that led to the creation of rich and diverse content for CINEJ. Osakue S. Omoera and Charles C. Okwuowulu's "Female Representation in Select Films of Frank Rajah Arase: Evidence of Male Chauvinist Tendencies in the Ghanaian Film Culture" looks at the constant resonance of feminine image misrepresentation in most narratives since the (re)invention of video-films in Nigeria, Ghana, and indeed across the African continent (Omoera and Okwuowulu, 2021). The authors claim that in spite of the binary struggle between the (presumed) chauvinist filmmakers and their feminist counterparts, masculinity always (re)emerges in new forms or topoi to dominate femininity. Consequently, there seems to be a paradigm shift on the (mis)representation of women that reinforces Laura Mulvey's sexual voyeuristic objectification of the feminine gender as reflected in near-nude costumes as well as sexually larded scenes that are common sights in African films, particularly those from Ghana.

Jora Vaso takes a look at Nadav Lapid's film Synonymes through " The Millennial Antinostalgic: Yoav in Nadav Lapid's Synonymes" article (Vaso, 2021). In this article, Vaso explores the idea of the contemporary, or millennial, exile as an artist in the making. This journey is best recounted in the film Synonymes (2019) by Israeli director Nadav Lapid, an autobiographical tale that chronicles the director's own exile from Israel to Paris and captures his journey toward becoming an artist. The paper references two prominently antinostalgic authors: 20th century Polish writer Witold Gombrowicz and Polsih-Jewish writer Henryk Grynberg. 
Alireza Farahbakhsh and Ramtin Ebrahimi in their "The Social Implications of Metaphor in Bong Joon-ho's Parasite" discuss the social implications of repetitive metaphors in the film (and of the word) Parasite (2019) and to observe what makes the life of a lower-class family parasitic within a typical capitalistic society (Farahbakhsh and Ebrahimi, 2021). Their present study offers a comprehensive analysis of its recurring metaphors as well as its treatment of the characters who visibly belong to two completely different classes. Through a complex story of two families whose fate gets intermingled, Bong Joon-ho masterfully presents a metaphoric picture of a society where inequality is rampant and the poor can only experience temporary happiness in the shadow of the rich (represented by the Park family).

Emwinromwankhoe Osakpolor in " Portrayal of Women in Contemporary Nollywood Films: Isoken and King of Boys in Focus" investigates the portrayal of women in contemporary Nollywood films, using Isoken (2017) and King of Boys (2018) as case studies (Osakpolor, 2021). The author's objective is to highlight the various ways in which women in the films are portrayed to viewers as well as relate these portrayals to the reinforcement of gender stereotypes and disparity in the Nollywood industry. Anchored on the cultivation theory, the study adopted the qualitative content analysis method. Findings showed that women in the studied films are negatively portrayed and that these portrayals follow the regular pattern of depiction of women in Nollywood. The researcher recommends that efforts should be made by Nollywood scriptwriters, producers and directors to depart from the status quo and portray Nigeria women in a positive light.

Maria del Carmen Molina Barea in " Cinema: Not Frames But Veils" intends to rethink the metaphors of the cinema as window and frame (Molina Barea 2021). The first one addresses the cinema as a transparent, open window that faithfully reproduces the world, taking the spectator's 
view beyond the screen guided by realism and indexicality. The second one takes the screen as a rectangular surface that focuses the audience's eye on the images that are produced inside its borders. After revisiting both notions, the author adds a third one inspired by the passe-partout of Derrida: the cinema as veil, also theorized as backdrop and decor. Ultimately, this approach explores the idea of simulacrum by analizing two examples: Blue (Apichatpong Weerasethakul, 2018) and Decor (Ahmad Abdalla, 2014).

Joel Robert Gwynne in "“not conducive for sobriety": Sex Addiction and Neoliberal Masculinity in Don Jon and Thanks for Sharing" looks at how both films depict the trials and tribulations of two men battling sex addiction (Gwynne, 2021). Both films share other similarities in their representation of the lives of unmarried men who are all approaching midlife, and who are all struggling to build meaningful, monogamous, long term attachments with women. This article is concerned with the relationship between sex addiction and masculinity, and how neoliberalism is imbued in the characters' embodiment of masculinity regardless of their divergent social backgrounds.

John Thomas McGuire in "Formation of the ambiguous heroic archetype: three Jewish-American film actors and the united states' film system, 1929-1948" argues that Paul Muni (1895-1967), Edward G. Robinson (1893-1973), and John Garfield (1913-1952) became the first important Jewish-American film actors to both enact and diversify the white Anglo-Saxon film dramatic actor archetype in the United States' studio system from 1929 through 1948 in two ways: the critical and commercial ascent of Muni and Robinson, capped by the former's becoming the first Jewish-American to win an Academy Award for Best Actor in 1937, and Robinson and Garfield's extension of the archetype into the film noir genre during the 1940s (McGuire, 2021). 
Jacob Hovind in "About miracles": seeing the "real thing" in hong sang-soo's woman on the beach and éric rohmer's le rayon vert" claims that Hong Sang-soo's cinema is one in which his characters consistently avoid reality, whether by constructing explanatory narratives and patterns or by turning other people into emotionally projected images (Hovind, 2021).

Jaya Upadhyay in "Waking (Dreaming): a vedantic reflection on richard linklater's film, Waking Life" attempts at a reading of the film Waking Life (2001) in the framework of the Indic philosophy of 'Vedanta,' more specifically the 'Advaita' or the non-dual school of Vedanta (Upadhyay, 2021). The author claims that the film's narrative is constructed out of the protagonist's dreamscapes. The itinerant protagonist moves through conversations within his dreams, trying to make sense of his 'wake walking' situation. These conversations take the form of a more significant philosophical reflection upon the conscious life of humans.

In "the liminal and the surreal: the space of limbo and dreams in Luis Bunuel's The Discreet Charm of the Bourgeoisie" Miniature Malekpour and Shooka Motamedi explore the role of liminality and Surrealism in Luis Bunuel's The Discreet Charm of the Bourgeoisie (Malekpour and Motamedi, 2021). By taking into consideration the relationship between Surrealism, Marxism and Freud, this paper identifies the role of the liminal and Bunuel's treatment of these topics. The purpose of this study is to examine the use of liminal space and Surrealism to identify the role of the bourgeois and their fears through the lens of Bunuel.

Pouria Torkamaneh, Farhad Poordakan, and Pedram Lalbakhsh in "Baudrillard, hyperreality, and the evil in othello and the hateful eight" claim that Shakespeare's tragedies and Quentin Tarantino's aesthetically violent films bear striking similarities in the problematization of both villainy and reality (Torkamaneh, Poordakan, and Lalbakhsh, 2021). The authors claim that such 
concerns reverberate the most in Othello (1604) and The Hateful Eight (2015). Although critical scholarship about both works abounds, this essay offers an alternative approach by consulting the thoughts of Jean Baudrillard on the issues of hyperreality, criminality, and terrorism.

Paul Animbom Ngong in "The reception of Cameroon Films and home videos in student residential areas: the case of Bambili - Cameroon" describes how film in Cameroon is valorised more through the home video system caused principally by the closure of theatre halls and the advent of cable TV channels dedicated to the broadcasting of movies for home consumption and the emergence of new media (Animbom Ngong, 2021). This study looks at the reception of these home videos particularly in the student residential area of Bambili - Cameroon. A total number of 500 students served as sample for the study whose results show that a majority of viewers choose films according to different criteria but mostly influenced by their horizons of expectations.

Violet Barman Deka in "The world of Assamese celluloid: 'yesterday and today'" argues that the Assamese cinema industry is evolving to be competent enough to connect to the rest of the world (Barman Deka, 2021). The author states that this small self-supported industry is also fraught with innumerable bottlenecks, be it financial constraints, technological shortcomings, or internal socio-political constrain. The world of Assamese celluloid: 'yesterday and today' explores the entire journey of the Assamese cinema, which means a journey that will narrate many stories from its past and present and also analyses its future potential. This paper deals with the new trend emerging in genres, technical advancement, and visual representation along with a trend that emphasized the commercial success of cinema by toeing the style of Bollywood and world cinema. It explores the new journey of Assamese cinema which deals with small 
budgets, realistic approaches, and portraying stories from the native lanes. It also touches upon the phase of 'freeze' that the Assamese cinema industry was undergoing due to global pandemic Covid-19.

Selen Gökçem Aky1ldız in "Disgraced of the west, deserted of the east: men in the films shame and issız adam" claims that, Shame (Steve McQueen, 2011) and Issız Adam (Çağan Irmak, 2008) have other analogies that require to study on (Gökçem Akyıldız, 2021). Even though both men live in different cultures and have different relationship models, they struggle in life concurrently. While Steve McQueen's Shame focuses on uncompromising sex addiction that overthrows a man's life, Çağan Irmak's Issız Adam takes it on a romantic level and presents a lonely man who cannot attach women.

Moshe Machlev in "I'll be back? the deconstruction of the 1980's and 1990's hard body movies" discusses the cultural factors that inspired the "hard body" movies of the 1980's and 1990's, but it also describes the changes that occurred, later on, that contributed to the deconstruction of those movies (Machlev, 2021). The author claims that the hard body movies were characterized by having a reoccurring set of actors (Schwarzenegger, Stallone, and Van Damme) and themes (facing adversaries in a forceful manner), and some of the factors that influenced this portrayal were the Reagan Revolution and a revaluation of the Vietnam war. However, a change in political ideology, and a reassessment of America's place in the world, inspired the deconstruction of those movies, and newer movies brought with them a new message, of what could be considered a soft body.

Moritz Wischert-Zielke in "The impulse-image of vampiric capital and the politics of vision and disability - evil and horror in don't breathe" examines affective and semiotic aspects of Don't 
Breathe's construction of evil and horror (Wischert-Zielke, 2021). The author intends to work towards a post-genre approach to horror, evil and horror are re-examined and differentiated on a discursive level in a first theoretic step. The article then takes Fede Álvarez' 2016 horror film Don't Breathe as its case. In a first part, it draws from the Marxian metaphor of vampiric capital and employs a Deleuzian approach to film in focusing on the impulse-image of Don't Breathe. In a second part, the analysis of evil and monstrous horror then takes into account political notions of the film's themes of blindness and (dis)ability, thereby moving from a (primarily) affective perspective to a rather semiotic discussion.

There are also four thorough book reviews by Buteanu (2021), Poloni (2021), Ulusoy (2021) and Wilmink (2021).

\section{REFERENCES:}

Akser, M. (2020). Cinema, life and other viruses: the future of filmmaking, film education and film studies in the age of covid-19 pandemic. CINEJ Cinema Journal, 8(2), 1-13.

Animbom Ngong, P. (2021). The reception of cameroon films and home videos in student residential areas: the case of bambili - cameroon. CINEJ Cinema Journal, 9(1), 371-392.

Barman Deka, B. (2021). The world of Assamese celluloid: 'yesterday and today'. CINEJ Cinema Journal, 9(1), 393-423.

Brook, O., O’Brien, D., \& Taylor, M. (2021). Inequality talk: How discourses by senior men reinforce exclusions from creative occupations. European Journal of Cultural Studies, $24(2), 498-513$.

Brown, M. (2021). Baftas 2021: Michaela Coel dedicates win to intimacy coordinator. Guardian 6 June. https://www.theguardian.com/culture/2021/jun/06/baftas-2021-michaela-coeldedicates-win-to-intimacy-coordinator 
Buteanu, I. (2021). Review of A Christian Approach to Cinema: Tarkovsky. Film as Prayer. CINEJ Cinema Journal, 9(1), 526-530.

Cobb, S., Newsinger, J., \& Nwonka, C. J. (2020). Introduction: Diversity in British Film and Television: Policy, Industry and Representation. Journal of British Cinema and Television, $17(1), 1-5$.

Davis, C. H., Shtern, J., Coutanche, M., \& Godo, E. (2018). Screenwriters in Toronto: Centre, Periphery, and Exclusionary Networks in Canadian Screen Storytelling. In J. Grant (Ed.) Seeking Talent for Creative Cities (pp. 77-98). University of Toronto Press.

Eikhof, D. R. (2020). COVID-19, inclusion and workforce diversity in the cultural economy: what now, what next?. Cultural Trends, 29(3), 234-250.

Farahbakhsh, A. and R. Ebrahimi (2021).The social implications of metaphor in bong joon-ho's parasite. CINEJ Cinema Journal, 9(1), 87-116.

Gökçem Akyıldız, S. (2021). disgraced of the west, deserted of the east: men in the films Shame and Issiz Adam. CINEJ Cinema Journal, 9(1), 424-455.

Grugulis, I., \& Stoyanova, D. (2012). Social capital and networks in film and TV: Jobs for the boys?. Organization studies, 33(10), 1311-1331.

Gwynne, J.L. (2021). "not conducive for sobriety": sex addiction and neoliberal masculinity in don jon and thanks for sharing. CINEJ Cinema Journal, 9(1), 181-199.

Hennekam, S., \& Syed, J. (2018). Institutional racism in the film industry: a multilevel perspective. Equality, Diversity and Inclusion. 37(6): 551-565.

Hovind, J. (2021). About Miracles": Seeing the "real thing" in Hong Sang-soo's Woman on the Beach and Éric Rohmer's Le Rayon vert. CINEJ Cinema Journal, 9(1), 246-291.

Jones, D., \& Pringle, J. K. (2015). Unmanageable inequalities: sexism in the film industry. The Sociological Review, 63, 37-49. 
Lourenço, J. (2021). O Ano em que o Cinema que conhecíamos parou: um retrato em três actos. Observatorio (OBS*) Journal, (2021, Special issue), 045-055.

http://obs.obercom.pt/index.php/obs/article/view/1904/pdf

Machlev, M. (2021). I'll be back? the deconstruction of the 1980's and 1990's hard body movies. CINEJ Cinema Journal, 9(1), 456-491.

Malekpour, M. and S. Motamedi. (2021). The Liminal and the Surreal: The Space of Limbo and Dreams in Luis Bunuel's The Discreet Charm of the Bourgeoisie. CINEJ Cinema Journal, $9(1), 320-345$.

Meadows, M. (1994). Re-claiming a cultural identity: Indigenous media production in Australia and Canada. Continuum, 8(2), 270-292.

McGuire, J.T. (2021). Formation of the ambiguous heroic archetype: three jewish-american film actors and the united states' film system, 1929-1948. CINEJ Cinema Journal, 9(1), 200245.

Molina Barea, M. d. C. (2021). Cinema: not frames but veils. CINEJ Cinema Journal, 9(1), 146180.

Nwonka, C. J., \& Malik, S. (2018). Cultural discourses and practices of institutionalised diversity in the UK film sector:'Just get something black made'. The Sociological Review, 66(6), 1111-1127.

Omoera, O. S. and C. C. Okwuowulu (2021). Female representation in select films of frank rajah arase: evidence of male chauvinist tendencies in the ghanaian film culture. CINEJ Cinema Journal, 9(1), 14-41.

Osakpolar, E. (2021). Portrayal of women in contemporary nollywood films: isoken and king of boys in focus. CINEJ Cinema Journal, 9(1), 117-145.

Poloni, M. (2021). Review of towards a political aesthetics of cinema. the outside of film. CINEJ Cinema Journal, 9(1), 531-537. 
Pulver, A. (2021, June 18). Golden Globes: two members resign from 'toxic' Hollywood Foreign Press Association. The Guardian. https:/www.theguardian.com/film/2021/jun/18/goldenglobes-two-members-resign-from-toxic-hollywood-foreign-press-association

Redden, E. (2020, June 15). A Long Time Coming. Inside Higher Ed. https://www.insidehighered.com/news/2020/06/15/ontario-design-college-embarks-blackfaculty-hiring-initiative

Sweeney, M. (2021, July 10). Lights, camera, studio space? Lack of production capacity hits UK film industry. The Guardian. https:/www.theguardian.com/film/2021/jul/10/lights-camerastudio-space-lack-of-production-capacity-hits-uk-film-industry

Torkamaneh, P., F. Poordakan, and P.Lalbakhsh (2021). Baudrillard, Hyperreality, and the Evil in Othello and The Hateful Eight. CINEJ Cinema Journal, 9(1), 346-370.

Ulusoy, N. (2021). Review of Shoe Reels: The History and Philosophy of Footwear in Film. CINEJ Cinema Journal, 9(1), 538-547.

Upadhyay, P. (2021) Waking (Dreaming): A Vedantic Reflection on Richard Linklater's film, Waking Life. CINEJ Cinema Journal, 9(1), 292-319.

Vaso, J. (2021). The millennial antinostalgic: yoav in nadav lapid's synonymes. CINEJ Cinema Journal, 9(1), 42-86.

Wilmink, M. (2021). Review of Theorizing Film Through Contemporary Art: Expanding Cinema. CINEJ Cinema Journal, 9(1), 548-556.

Wischert-Zielke, M. (2021). The Impulse-Image of Vampiric Capital and the Politics of Vision and Disability - Evil and Horror in Don't Breathe. CINEJ Cinema Journal, 9(1), 456-491. 